\title{
HUBUNGAN KEJADIAN ANEMIA PADA IBU MENYUSUI DENGAN STATUS GIZI BAYI USIA 7-12 BULAN
}

\author{
Nugraheni Saptyaningtiyas, Aryu Candra Kusumastuti*) \\ Program Studi Ilmu Gizi Fakultas Kedokteran Universitas Diponegoro \\ Jl.Dr.Sutomo No.18, Semarang, Telp (024) 8453708, Email : gizifk@ undip.ac.id
}

\begin{abstract}
Background: Anemia is main problem in pregnant and lactating women. It was related with their micronutrient intake such as iron, folic acid and vitamin B12. Anemia on lactating mothers can be related to meternal parenting, quality and quantity breastmilk affect nutritional status of infants.

Objective: This study was aimed to determine the relationship between the incidence of anemia on lactating mothers and nutritional status of infants aged 7-12 months.

Methods: This study used cross-sectional design with 51 lactating mothers as subjects which were selected by purposive sampling. Mothers' hemoglobin levels were measured using the Cyanmethemoglobin method, infants weight were measured using Baby Scale, mother micronutrients intake were obtained by 24-hour Recall method and complementary feeding was obtained by Food Frequency Questionnaire (FFQ) method, then both of them were calculated by nutrisoft. Chi Square test was used for bivariate analysis.

Results: The results showed 58.8\% of lactating mothers were anemic and 9,8\% of infants aged 7-12 months were undernutrition. The mean of mothers' hemoglobin level was 11,8 gr/dL and the mean $z$-score of infants was $-0.40 \pm$ 1.00 SD. Complementary feeding intake 74,5\% was categorized as deficient. There was no significant relationship between the incidence of anemia on lactating mothers and nutritional status of infants aged 7-12 months $(p=0,95)$ and there was also no significant relationship between complementary feeding and nutritional status of infants aged 7-12 months $(p=0,16)$.
\end{abstract}

Conclusions: There was no significant relationship between the incidence of anemia on lactating mothers and nutritional status of infants aged 7-12 months.

Keywords: anemia; lactating mothers; nutritional status; infants; complementary feeding

\section{ABSTRAK}

Latar Belakang : Anemia merupakan masalah utama pada wanita hamil dan menyusui. Hal tersebut berkaitan dengan defisiensi asupan mikronutrien seperti zat besi, asam folat dan vitamin B12. Anemia pada ibu dapat berhubungan dengan pola asuh ibu, kualitas dan kuantitas ASI yang akan berpengaruh pada status gizi bayi.

Tujuan : Penelitian ini bertujuan untuk mengetahui hubungan kejadian anemia pada ibu menyusui dengan status gizi bayi usia 7-12 bulan.

Metode : Desain penelitian cross-sectional dengan subjek 51 ibu menyusui yang dipilih secara purposive sampling. Kadar hemoglobin ibu diukur menggunakan metode Cyanmethemoglobin, berat badan bayi diukur dengan Baby Scale. Asupan mikronutrien ibu diperoleh dengan metode Recall 24 jam dan asupan MPASI diperoleh dengan metode Food Frequency Questionnaire (FFQ) kemudian dihitung dengan nutrisoft. Analisis bivariat menggunakan uji Chi Square.

Hasil : Hasil penelitian menunjukkan bahwa 58,8\% ibu menyusui mengalami anemia dan 9,8\% bayi usia 7-12 bulan mengalami gizi kurang. Rerata kadar hemoglobin ibu 11,8 gr/dL dan rerata

z-score bayi -0,40 \pm 1,00 SD. Asupan MPASI 74,5\% tergolong kurang. Tidak ada hubungan bermakna antara kejadian anemia pada ibu menyusui dengan status gizi bayi usia 7-12 bulan $(p=0,95)$ dan tidak ada hubungan bermakna antara asupan MPASI dengan status gizi bayi usia 7-12 bulan $(p=0,16)$.

Simpulan : Tidak ada hubungan antara kejadian anemia ibu menyusui dengan status gizi bayi usia 7-12 bulan.

Kata Kunci : anemia; ibu menyusui; status gizi; bayi; MPASI

\section{PENDAHULUAN}

Air Susu Ibu (ASI) merupakan sumber gizi sangat ideal dan aman bagi bayi. ASI dapat memenuhi kebutuhan gizi bayi untuk 6 bulan pertama, menyediakan $3 / 4$ bagian protein yang dibutuhkan bayi usia 6-12 bulan dan masih merupakan sumber yang cukup berarti untuk beberapa bulan berikutnya. ${ }^{1}$
Bayi yang mendapat asupan makanan cukup sesuai umur dapat meningkatkan berat badan berhubungan dengan status gizi $(\mathrm{BB} / \mathrm{U})$. Menurut Riskesdas 2010 prevalensi status gizi pada usia $6-11$ bulan yaitu $4,7 \%$ gizi buruk, $8,5 \%$ gizi kurang, $81,7 \%$ gizi baik, dan $5,0 \%$ gizi lebih. ${ }^{2}$

Masalah yang sering terjadi pada kelompok dewasa yaitu wanita usia subur (WUS) 
terutama wanita hamil dan menyusui salah satunya adalah anemia. ${ }^{3}$ Anemia sering terjadi terutama di negara berkembang (developing countries) dan pada kelompok sosial ekonomi menengah kebawah. ${ }^{3}$ Anemia yang terjadi disebabkan kurang konsumsi asupan mikronutrien dalam makanan sehari-hari. ${ }^{4}$

Menurut Riskesdas 2007, angka anemia pada wanita usia subur (WUS) sebesar 24,5\%. Pernyataan ini didukung dengan tingginya prevalensi anemia di Jawa Tengah sebesar 57,7\% yang lebih tinggi daripada prevalensi anemia WHO (2005) sebesar $41,8 \%$ dan prevalensi anemia nasional sebesar 50,9\%. ${ }^{6,7}$ Prevalensi anemia ibu hamil di Kota Semarang tahun 2011 sebesar 17,93\% dan mengalami peningkatan tahun 2012 sebesar $19,14 \%{ }^{8}$

Penelitian di Meksiko 2006 menunjukkan bahwa riwayat anemia ibu dan peningkatan durasi menyusui dapat dihubungkan sebagai faktor risiko anemia pada bayi usia 9 bulan. ${ }^{9}$ Penelitian di India tahun 2005 menunjukkan bahwa prevalensi gizi buruk pada bayi usia 6-11 bulan lebih tinggi daripada usia 0-5 bulan karena bayi usia lebih dari 6 bulan rentan kekurangan gizi akibat buruknya praktik pemberian MPASI. ${ }^{10}$ Penelitian di Tanzania tahun 2006 menyebutkan bahwa karakteristik ibu dan praktik pemberian makan dapat mempengaruhi status gizi bayi. ${ }^{11}$

Berdasarkan paparan di atas, peneliti tertarik untuk mengkaji hubungan kejadian anemia pada ibu menyusui dengan status gizi bayi usia 712 bulan. Penelitian ini diharapkan dapat memberikan informasi dan pengetahuan mengenai hubungan anemia pada ibu menyusui dengan status gizi bayi usia 7-12 bulan serta dapat dijadikan pertimbangan dalam pengambilan kebijakan mengenai program penanganan anemia pada ibu menyusui dan status gizi bayi usia 7-12 bulan.

\section{METODE PENELITIAN}

Penelitian ini dilakukan pada ibu menyusui di wilayah kerja Puksesmas Ngemplak Simongan karena di wilayah tersebut memiliki prevalensi anemia tergolong tinggi pada 3 tahun terakhir. Waktu pelaksanaan penelitian ini adalah bulan Mei-Juni 2013. Penelitian ini termasuk lingkup gizi masyarakat dengan desain cross sectional. Jumlah sampel penelitian ini sebanyak 51 sampel yang dipilih secara purposive sampling. Kriteria inklusi penelitian ini adalah ibu menyusui yang memiliki bayi usia 7-12 bulan, ibu berusia 20-35 tahun, ibu rumah tangga dan mengasuh sendiri bayinya, ibu dan bayi tidak sedang sakit selama dan 2 minggu sebelum dilaksanakan penelitian, tidak mempunyai riwayat penyakit kronis, bayi tidak cacat, tidak mempunyai kelainan bawaan sejak lahir. Kriteria eksklusi penelitian ini adalah mengundurkan diri sebagai sampel penelitian.

Variabel independen penelitian ini adalah kejadian anemia pada ibu menyusui. Variabel dependen penelitian ini adalah status gizi bayi usia 7-12 bulan. Asupan Makanan Pendamping ASI (MPASI) merupakan variabel perancu penelitian ini karena merupakan faktor yang dapat mempengaruhi status gizi bayi usia 7-12 bulan. Data yang dikumpulkan dalam penelitian ini adalah identitas ibu dan bayi, kadar hemoglobin ibu, asupan mikronutrien ibu menyusui seperti asupan zat besi (Fe), asam folat dan vitamin B12, berat badan bayi dan asupan makanan pendamping ASI (MPASI) bayi. Selain variabel di atas data yang diambil antara lain pendapatan keluarga dan jumlah anggota keluarga.

Kejadian anemia pada ibu menyusui didefinisikan sebagai suatu keadaan dimana kadar hemoglobin $(\mathrm{Hb})$ di dalam darah ibu menyusui lebih rendah dari nilai normal yang diukur menggunakan metode Cyanmethemoglobin. Pengambilan darah dilakukan oleh tenaga ahli dengan cara mengumpulkan ibu menyusui di kelurahan kemudian dianalisis di salah satu Laboratorium Swasta di Semarang. Hasilnya dikategorikan menjadi anemia ( $\mathrm{Hb}<12 \mathrm{mg} / \mathrm{dL})$ dan normal $(\mathrm{Hb} \geq 12 \mathrm{mg} / \mathrm{dL}){ }^{4}$ Usia ibu menyusui didapatkan dari selisih antara tahun penelitian dengan tahun kelahiran ibu yang diperoleh dari wawancara dan mengecek kebenaran data dengan melihat kartu identitas responden (KTP), hasil dinyatakan dalam tahun.

Asupan mikronutrien ibu yaitu zat besi $(\mathrm{Fe})$, asam folat dan vitamin B12 ibu menyusui didefinisikan sebagai jenis dan jumlah asupan zat besi (Fe), asam folat dan vitamin B12 bersumber dari makanan yang dikonsumsi sehari-hari dan diukur dengan metode Recall 24 jam. Data asupan zat besi (Fe), asam folat dan vitamin B12 diambil setiap satu minggu sekali dan diperoleh dalam ukuran rumah tangga kemudian dihitung menggunakan nutrisoft. Asupan zat besi $(\mathrm{Fe})$, asam folat dan vitamin B12 dibandingkan dengan AKG ibu menyusui dan dinyatakan dalam persen. Hasil dikategorikan menjadi cukup $(\geq 100 \%)$ dan kurang $(<100 \%)$.

Berat badan bayi didapatkan dari pengukuran langsung satu kali saat melakukan penelitian. Berat badan bayi diukur menggunakan Baby Scale dengan kapasitas $20 \mathrm{~kg}$ dan tingkat 
ketelitian $0,1 \mathrm{~kg}$ dalam keadaan berpakaian minimal tanpa perlengkapan apapun (tanpa sepatu, topi, dll). Usia bayi 7-12 bulan didapatkan dari selisih antara bulan penelitian dengan bulan kelahiran bayi melalui wawancara dengan ibu dan mengecek kebenaran data pada Kartu Menuju Sehat (KMS), hasil dinyatakan dalam bulan.

Status gizi bayi usia 7-12 bulan merupakan keseimbangan antara zat gizi yang masuk ke dalam tubuh dengan kebutuhan gizi yang diperlukan tubuh dan dinilai menggunakan indikator berat badan menurut umur $(\mathrm{BB} / \mathrm{U})$. Indikator ini dilihat melalui pengukuran $\mathrm{Z}$-score dan dikategorikan menjadi gizi kurang $(<-2 \mathrm{SD})$ dan gizi baik $(\geq-2 \mathrm{SD})$.

Asupan makanan pendamping ASI (MPASI) didefinisikan sebagai jenis dan jumlah makanan dan minuman yang dikonsumsi bayi untuk memenuhi kebutuhan gizinya. Data diperoleh menggunakan metode FFQ (Food Frequency Questionaire) semi kuantitatif yang diambil sekali selama penelitian dan diperoleh dalam ukuran rumah tangga kemudian dikonversi dalam satuan kkal yang dihitung menggunakan nutrisoft. Asupan energi yang didapat dibandingkan dengan AKG bayi usia 7-12 bulan kemudian dinyatakan dalam persen. Hasil dikategorikan menjadi cukup $(\geq$ $100 \%)$ dan kurang $(<100 \%)$.

Analisis univariat dilakukan untuk mengidentifikasi usia ibu dan bayi, pendidikan ibu, kadar hemoglobin ibu, asupan mikronutrien ibu, berat badan bayi dan asupan MPASI bayi. Analisis bivariat dengan uji Chi Square untuk mengetahui hubungan kejadian anemia pada ibu menyusui dan asupan MPASI bayi dengan status gizi bayi usia 712 bulan

\section{HASIL PENELITIAN}

Karakteristik Ibu Menyusui

Jumlah sampel dalam penelitian ini adalah 51 sampel. Pada penelitian ini didapatkan usia ibu menyusui rata-rata 26-30 tahun (37,3\%) dan pendidikan terakhir ibu adalah SMA/SMK (49,0\%). Pendapatan keluarga tertinggi Rp $5.000 .000,00$ dan terendah $\mathrm{Rp}$ 400.000,00. Karakteristik ibu dilihat pada tabel 1

Tabel 1. Karakteristik ibu

\begin{tabular}{rcc}
\hline & n & \% \\
\hline Usia Ibu & & \\
$-\quad 20-25$ tahun & 18 & $35,3 \%$ \\
$-\quad 26-30$ tahun & 19 & $37,3 \%$ \\
$-\quad$ 31-35 tahun & 14 & $27,4 \%$ \\
\hline Pendidikan Ibu & & \\
- SD & 5 & $9,8 \%$ \\
- SMP & 10 & $19,6 \%$ \\
$-\quad$ SMA/SMK & 25 & $49,0 \%$ \\
$-\quad$ Diploma & 8 & $15,7 \%$ \\
- Sarjana & 3 & $5,9 \%$ \\
\hline Pendapatan Keluarga & & \\
$-\quad \geq$ Rp 1.200.000,00 & 27 & $52,9 \%$ \\
$-\quad$ Rp 1.200.000,00 & 25 & $47,1 \%$ \\
\hline
\end{tabular}

\section{Kadar Hemoglobin Ibu Menyusui}

Hasil pemeriksaan anemia pada ibu menyusui dilihat dari kadar hemoglobin menunjukan bahwa kadar hemoglobin ibu terendah $8,6 \mathrm{gr} / \mathrm{dL}$ dan tertinggi $15,6 \mathrm{gr} / \mathrm{dL}$ serta reratanya adalah 11,8 gr/dL. Di wilayah kerja Puskesmas Ngemplak Simogan sebanyak 30 ibu $(58,8 \%)$ anemia sedangkan menurut wilayah kelurahan yaitu di Kelurahan Ngemplak Simongan dari 23 ibu yang diukur terdapat $15 \mathrm{ibu}(65,2 \%)$ anemia dan di Kelurahan Bongsari dari 28 ibu yang diukur terdapat $15 \mathrm{ibu}(53,6 \%)$ anemia. Berikut adalah distribusi frekuensi kadar hemoglobin ibu menyusui.

Tabel 2. Kadar hemoglobin

\begin{tabular}{cccc}
\hline \multirow{2}{*}{ Wilayah Kelurahan } & \multicolumn{2}{c}{ Kategori Hb } & \multirow{2}{*}{ Total } \\
\cline { 2 - 3 } & Normal & Anemia & \\
\hline Ngemplak Simongan & $8(34,8 \%)$ & $15(65,2 \%)$ & $23(100 \%)$ \\
Bongsari & $13(46,4 \%)$ & $15(53,6 \%)$ & $28(100 \%)$ \\
\hline \multicolumn{1}{c}{ Total } & $\mathbf{2 1}(\mathbf{4 1 , 2 \% )}$ & $\mathbf{3 0}(\mathbf{5 8 , 8 \% )}$ & $\mathbf{5 1 ( 1 0 0 \% )}$ \\
\hline
\end{tabular}


Kecukupan Asupan Mikronutrien Ibu menyusui sebagian besar termasuk kategori kurang Menyusui dari kebutuhan. Berikut adalah distribusi frekuensi

Asupan mikronutrien seperti asupan zat kecukupan asupan mikronutrien ibu menyusui. besi $(\mathrm{Fe})$, asam folat dan vitamin B12 pada ibu

Tabel 3. Kecukupan Asupan Mikronutrien

\begin{tabular}{lrc}
\hline & n & \% \\
\hline Kecukupan Asupan Zat besi & & \\
$-\quad$ Cukup & 2 & $3,9 \%$ \\
$-\quad$ Kurang & 49 & $96,1 \%$ \\
\hline Kecukupan Asupan Asam folat & & \\
$\quad-\quad$ Cukup & 0 & 0 \\
$-\quad$ Kurang & 51 & $100 \%$ \\
\hline Kecukupan Asupan Vitamin B12 & & \\
$\quad-\quad$ Cukup & 7 & $13,7 \%$ \\
$-\quad$ Kurang & 44 & $86,3 \%$ \\
\hline
\end{tabular}

\section{Karakteristik Bayi}

Pada penelitian ini rerata $z$-score bayi usia $7-12$ bulan adalah $-0,40 \pm 1,00 \mathrm{SD}$, nilai terendah 2,75 dan tertinggi 1,69. Hasil pengukuran antropometri untuk melihat status gizi bayi berdasarkan $\mathrm{BB} / \mathrm{U}$ menunjukan bahwa sebanyak 5 bayi $(9,8 \%)$ termasuk gizi kurang. Asupan energi (MPASI) sebesar 74,5\% termasuk kategori kurang. Distribusi frekuensi dapat dilihat pada tabel 4.

Tabel 4. Karakteristik bayi

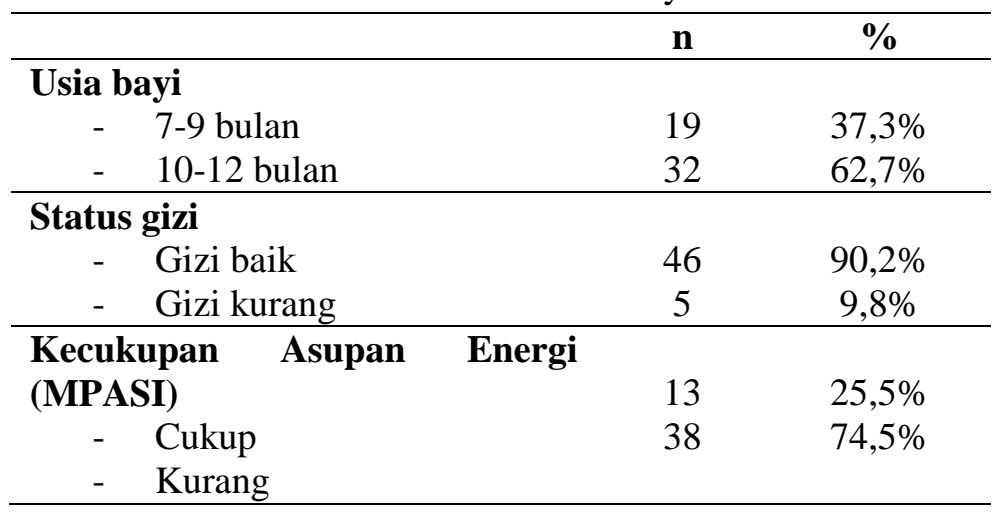

Berdasarkan pengkajian asupan MPASI diketahui asupan makan bayi yaitu makanan pokok antara lain bubur susu, nasi tim dan nasi biasa dikonsumsi 2-3 kali sehari sedangkan bubur nasi rata-rata dikonsumsi pagi hari. Konsumsi bubur susu, bubur nasi dan nasi tim kadang diselangseling dalam seminggu. Namun, ada 7 bayi $(13,7 \%)$ yang hanya mengkonsumsi bubur susu setiap hari. Lauk hewani antara lain daging ayam, ikan, telur dikomsumsi rata-rata 2 kali seminggu dan lauk nabati yaitu tahu dan tempe hampir tiap hari dikonsumsi maksimal 1 potong serta sayur yang paling sering adalah sayur bayam dan sayur sop rata-rata dikonsumsi 3 kali seminggu. Buahbuahan yang banyak dikonsumsi antara lain jeruk bayi, pepaya dan pisang ambon dengan frekuensi masing-masing 1 kali sehari untuk selingan dan dalam seminggu hanya 3 kali. Biskuit untuk selingan dikonsumsi hampir tiap hari yaitu 1-2 kali sehari.

Hubungan Kejadian Anemia pada Ibu Menyusui dengan Status Gizi Bayi

Usia 7-12 Bulan

Ibu menyusui yang anemia sebanyak 27 ibu $(90,0 \%)$ dengan status gizi bayi tergolong gizi baik, sedangkan $3 \mathrm{ibu}(10 \%)$ anemia dengan status gizi bayi tergolong gizi kurang. Ibu menyusui dengan kadar hemoglobin normal sebanyak $2 \mathrm{ibu}$ $(9,5 \%)$ dengan status gizi bayi tergolong gizi kurang. Dari analisis menggunakan uji Chi Square diperoleh nilai $\mathrm{p}>0,05$ sehingga dapat disimpulkan bahwa tidak ada hubungan bermakna antara kejadian anemia pada ibu menyusui dengan 
status gizi bayi usia 7-12 bulan. Tabel silang ditampilkan melalui tabel 6 .

Tabel 6. Tabel silang kadar hemoglobin ibu dengan status gizi bayi

\begin{tabular}{lccccc}
\hline & \multicolumn{2}{c}{ Status gizi } & & \multirow{2}{*}{ Total } \\
\cline { 3 - 4 } & & Gizi baik & $\begin{array}{c}\text { Gizi } \\
\text { kurang }\end{array}$ & \\
\cline { 3 - 4 } & Normal & $\mathbf{n}(\%)$ & $\mathbf{n}(\%)$ & & \\
\hline Kadar & $19(90,5 \%)$ & $2(9,5 \%)$ & 21 & 0,955 \\
Hemoglobin & & & $(100 \%)$ & \\
& Anemia & $27(90,0 \%)$ & $3(10,0 \%)$ & 30 & $(100 \%)$ \\
\hline Total & & & $\mathbf{5 1}$ & \\
& & $\mathbf{4 6}(\mathbf{9 0 , 2 \%})$ & $\mathbf{5 ( 9 , 8 \% )}$ & $\mathbf{( 1 0 0 \% )}$ & \\
\hline
\end{tabular}

Hubungan Asupan MPASI dengan Status Gizi Bayi Usia 7-12 bulan

Faktor lain yang mempengaruhi status gizi bayi usia 7-12 bulan adalah asupan MPASI. Asupan energi dalam MPASI kurang pada bayi dengan status gizi baik sebanyak 33 bayi $(86,8 \%)$ dan gizi kurang sebanyak 5 bayi $(13,2 \%)$. Dari analisis menggunakan uji Chi Square diperoleh nilai $\mathrm{p}>0,05$ sehingga dapat disimpulkan bahwa tidak ada hubungan bermakna antara asupan MPASI dengan status gizi bayi usia 7-12 bulan. Tabel silang ditampilkan melalui tabel 7 .

Tabel 7. Tabel silang asupan MPASI dengan status gizi

\begin{tabular}{llcccc}
\hline & \multicolumn{2}{c}{ Status gizi } & & \multirow{2}{*}{ Total } \\
\cline { 3 - 4 } & & Gizi baik & $\begin{array}{c}\text { Gizi } \\
\text { kurang }\end{array}$ & & value \\
\cline { 3 - 4 } & & $\mathbf{n}(\%)$ & $\mathbf{n}(\%)$ & & \\
\hline Asupan energi & Cukup & $13(100 \%)$ & $0(0 \%)$ & $13(100 \%)$ & 0,168 \\
(MPASI) & Kurang & $33(86,8 \%)$ & $5(13,2 \%)$ & $38(100 \%)$ & \\
\hline Total & & $\mathbf{4 6}(\mathbf{9 0 , 2 \%})$ & $\mathbf{5 ( 9 , 8 \% )}$ & $\mathbf{5 1 ( 1 0 0 \% )}$ & \\
\hline
\end{tabular}

\section{PEMBAHASAN}

Kejadian anemia pada ibu menyusui dalam penelitian ini ditunjukkan dengan sebagian besar ibu menyusui yang diukur memiliki kadar hemoglobin

$<12$ gr/dL. ${ }^{4}$ Prevalensi anemia yang didapat termasuk tinggi $(58,8 \%)$ karena melebihi target yang ditetapkan oleh Dinas Kesehatan Kota Semarang sebesar

$<23 \%{ }^{8}$ dan melebihi angka prevalensi anemia di Jawa Tengah sebesar $57,7 \%$. $^{7}$ Hal tersebut disebabkan kurangnya asupan zat gizi pembentuk darah seperti zat besi $(\mathrm{Fe})$, asam folat dan vitamin B12 yang merupakan faktor penyebab penurunan nilai hemoglobin. ${ }^{3}$ Selain itu, banyak ibu yang selama menyusui tidak mengkonsumsi tablet tambah darah dimana memang belum ada program pemerintah mengenai pemberian tablet tambah darah untuk ibu menyusui.

Asupan zat besi, asam folat dan vitamin B12 hampir sebagian besar termasuk kategori kurang. Hal tersebut disebabkan adanya faktor pendapatan keluarga atau daya beli, perilaku makan yang salah dan makanan yang dikonsumsi kurang variasi. ${ }^{12}$ Dalam penelitian ini ibu menyusui kurang mengkonsumsi bahan makanan sumber zat besi dan vitamin B12 seperti sumber hewani (telur ayam, hati ayam dan ikan) dan sering mengkonsumsi teh (menghambat penyerapan zat besi). ${ }^{13}$ Selain itu frekuensi ibu menyusui mengkonsumsi sayuran hijau juga kurang sedangkan bahan makanan sumber folat adalah sayuran hijau. ${ }^{14}$ Jenis sayur yang banyak dikonsumsi oleh ibu menyusui adalah sayur sop, sayur lodeh dan tumis-tumisan. Konsumsi buah sumber vitamin $\mathrm{C}$ seperti pisang, jeruk dan pepaya frekuensinya sedikit.

Pendapatan keluarga dalam penelitian ini sebagian besar tergolong cukup, ${ }^{15}$ namun asupan mikronutrien ibu tetap belum terpenuhi. Hal tersebut sesuai dengan penenelitian ini bahwa asupan mikronutrien yaitu asupan zat besi $(\mathrm{Fe})$, asam folat dan vitamin B12 yang didapat dengan metode recall masih kurang dari AKG yang dianjurkan dan pola makan sehari-hari kurang bervariasi. Pendapatan keluarga juga dapat 
mempengaruhi pola asuh ibu dalam memberikan makan bagi bayi. Hal tersebut ditunjukkan dengan sebagian besar asupan MPASI bayi tergolong kurang. Jika tingkat pendapatan tinggi maka jumlah dan jenis makanan cenderung membaik. Namun, mutu makanan tidak selalu membaik jika tidak membeli pangan atau bahan pangan berkualitas gizi tinggi. ${ }^{16}$

Pada penelitian ini didapatkan 5 bayi $(9,8 \%)$ termasuk status gizi kurang. Prevalensi tersebut lebih tinggi dari prevalensi status gizi kurang pada usia 6-11 bulan berdasarkan $\mathrm{BB} / \mathrm{U}$ menurut Riskesdas 2010 sebesar 8,5\%. ${ }^{2}$ Hal tersebut disebabkan karena asupan MPASI secara kualitas dan kuantitas masih tergolong kurang. Pemberian asupan MPASI bayi usia 7-12 bulan harus bertahap dengan melihat usia, jenis, frekuensi dan jumlah pemberian. ${ }^{17}$ Selain itu, juga harus mempunyai kualitas dan kuantitas yang baik. Pemberian MPASI juga disesuaikan dengan anjuran Kemenkes RI bahwa anak usia 7-9 bulan harus diberikan makanan lumat seperti bubur susu, pisang dikerok, dll. Bayi usia 10-12 bulan dapat diberikan makanan lunak seperti nasi tim bahkan jika sudah berusia 12 bulan dapat diberikan nasi biasa dengan sayur dan lauk yang beraneka ragam tetapi tetap melihat kemampuan pencernaan bayi. ${ }^{18}$

Hasil penelitian ini menunjukan tidak ada hubungan kejadian anemia pada ibu menyusui dengan status gizi bayi usia 7-12 bulan. Hal tersebut disebabkaan karena rerata kadar hemoglobin ibu 11,8 gr/dL dan termasuk anemia ringan. Anemia ringan pada ibu menyusui hanya berpengaruh pada kualitas ASI, sedangkan untuk anemia berat $(<8 \mathrm{mg} / \mathrm{dL})$ akan berpengaruh pada kualitas dan kuantitas ASI. ${ }^{19}$ Keadaan anemia ringan sering tidak menimbulkan gejala yang tampak tetapi dalam jangka panjang dapat berefek menjadi anemia berat dan dapat mempengaruhi status gizi bayi secara bertahap sehingga jika tidak segera ditangani dapat berpengaruh pada status gizi bayi sampai usia bayi 2 tahun. ${ }^{20}$

Hasil penelitian juga menunjukkan tidak ada hubungan asupan MPASI dengan status gizi bayi usia 7-12 bulan. Dalam penelitian ini asupan MPASI kurang, status gizi bayi masih dapat tergolong baik. Hal tersebut dikarenakan bayi pada usia bayi 7-12 bulan masih mendapat ASI sehingga kebutuhan bayi masih dapat terpenuhi dan asupan MPASI belum mempengaruhi status gizi bayi. Pada bayi usia lebih dari 12 bulan frekuensi asupan MPASI lebih banyak sehingga jika MPASI kurang maka dapat mempengaruhi status gizi bayi. ${ }^{21}$ Hasil tersebut tidak sejalan dengan hasil penelitian di
Yogyakarta tahun 2009 yang menunjukkan bahwa asupan MPASI dilihat dari tingkat kecukupan energi berhubungan dengan status gizi bayi. Namun, asupan MPASI tidak dapat menjadi faktor penyebab utama terhadap status gizi bayi. ${ }^{22}$

Status gizi bayi juga dipengaruhi asupan ASI, penyakit infeksi dan pola asuh ibu. Pola asuh ibu dipengaruhi antara lain pengetahuan ibu tentang gizi, pendidikan ibu, pekerjaan ibu, pendapatan keluarga. Ibu sangat berperan dalam mengatur asupan makan bayi. Selain itu, pendapatan keluarga merupakan faktor yang paling menentukan kualitas dan kuantitas makanan yang nantinya dapat mempengaruhi status gizi bayi. ${ }^{23}$

Pendidikan ibu berpengaruh terhadap praktik pemberian makan keluarga termasuk pemberian makan bayi yang berakibat pada status gizi. Hal tersebut sesuai dengan penelitian di Bogor tahun 2004 yang menyatakan bahwa semakin tinggi pendidikan ibu maka semakin baik perilaku ibu dalam memberi makan pada bayi sehingga semakin baik status gizi bayi. ${ }^{24}$ Pendidikan ibu yang rendah dapat membuat ibu kurang memperhatikan dirinya seperti kurangnya variasi makanan yang dikonsumsi. Oleh karena itu pendidikan ibu terkait asupan ibu penting untuk diperhatikan. Pendidikan juga mempunyai hubungan erat dengan pengetahuan sehingga walaupun pendidikan ibu rendah belum tentu kurang pengetahuan tentang gizi. Peningkatan pengetahuan dapat diperoleh dari pendidikan formal maupun pendidikan non formal. ${ }^{25}$

\section{SIMPULAN}

Tidak ada hubungan bermakna antara kejadian anemia pada ibu menyusui dengan status gizi bayi usia 7-12 bulan dan tidak ada hubungan bermakna asupan MPASI dengan status gizi bayi usia $7-12$ bulan

\section{UCAPAN TERIMA KASIH}

Puji syukur penulis panjatkan kepada Allah SWT atas segala rahmat dan kemudahan yang telah diberikan untuk dapat menyelesaikan artikel ini. Ucapan terima kasih ditujukan kepada pembimbing dan dosen penguji atas saran dan bimbingannya dalam penyusunan artikel ini; semua responden di Kelurahan Ngemplak Simongan dan Bongsari atas partisipasi dan kerjasama dalam penelitian; tidak lupa pula ucapan terima kasih kepada kedua orang tua; teman-teman Gizi 2009; serta semua pihak yang telah mendukung dalam penelitian. 


\section{DAFTAR PUSTAKA}

1. Adriani Merryana, Bambang Wirjadmadi. Peranan Gizi dalam Siklus Kehidupan. Jakarta : Kencana Perdana Media Group. 2012.

2. Riset Kesehatan Dasar. Jakarta : Badan Penelitian Kesehatan Kementrian Kesehatan RI. 2010.

3. Departemen gizi dan kesehatan masyarakat FKMUI. Gizi dan Kesehatan Masyarakat. Jakarta : PT Raja Grafindo Persada. 2007 hal 200-201 ; 205-206

4. Arisman, MB. Gizi Dalam Daur Kehidupan. Jakarta: EGC, 2007.

5. Riset Kesehatan Dasar. Jakarta : Badan Penelitian Kesehatan Kementrian Kesehatan RI. 2007.

6. WHO. Worlwide Prevalence of Anaemia 19932005. WHO Global database on anaemia CDC Atlanta. WHO Press: 2008.

7. Dinas Kesehatan Provinsi. Kumpulan Laporan Program Gizi Tahun 2009. Dinas Kesehatan Provinsi. 2009.

8. Dinas Kesehatan Kota. Kumpulan Laporan Program Gizi Tahun 2012. Dinas Kesehatan Kota Semarang. 2012

9. Jareen K. Meinzen-Derr, M. Lourdes Guerrero, Mekibib Altaye, et al. Risk of Infant Anemia Is Association with Exclucive Breast-Feeding and Maternal Anemia in Mexican Cohort. Journal of Nutrition. 2006.136 : 452-458,

10. Banerjee . B, O.N. Mandal. 2005. An Intervention Study in Malnutrition Among Infants in a Tribal Community of West Bengal. Indian Journal of Community Medicine Vol.30, No.1

11. Nyaruhucha, J.M Msuya, P.S. Mamiro and A.J.Kerengi. Nutritional status and feeding practices of under-five children in Simanjiro District, Tanzania. Tanzania Health Research Bulletin, Vol. 8, No. 3, 2006 pp. 162-167

12. I Dewa Nyoman S, Bachyar B, Ibnu F. Penilaian Status Gizi. Jakarta: Penerbit Buku Kedokteran EGC; 2001;191-208.

13. Mahan, L.Kathleen and Stump, Sylvia Escott.. Krause's Food \& The Nutrition Care Process. Edisi 13. Philadelpia : WB Saunders Co. 2012.p 731- 738

14. Ball GFM. Vitamins in Food; Analysis, Bioavailbility, and Stability. United States: CRC Press. 2006.p231 -305.

15. Badan Pusat Statistik. Semarang dalam Angka. Semarang. 2012

16. Hidayat., Alimul, A. Pangan Ilmu Keperawatan Anak. Jakarta : Salemba medika. 2005.

17. Departemen Kesehatan RI, Direktorat Jenderal Bina Kesehatan Masyarakat. Pedoman Umum Pemberian Makanan Pendamping Air Susu Ibu (MP-ASI) Lokal. Jakarta : Depkes RI. 2006.

18. Kementrian Kesehatan RI. Pedoman Kader Seri Kesehatan Anak, Jakarta. 2010 hal. 27-29;41-43

19. WHO, UNICEF, UNU. Iron deficiency anaemia: assessment, prevention and control, a guide for programme managers. Geneva, World Health Organization, 2001.

20. Ikatan Dokter Anak Indonesia. Nutrisi Pediatrik dan Penyakit Metabolik Jilid 1. Jakarta : Badan Penerbit IDAI. 2011.

21. Monte C, Gigliani ERJ. Recommendations for the complementary feeding of the breastfed child. Jornal de Pediatria 2004; 80: S131-S141.

22. Septiana, Rika. Hubungan Antara Pola Pemberian Makanan Pendamping ASI (MPASI) dengan Status Gizi Bayi Usia 6-24 bulan di Wilayah Kerja Puskesmas Gedongtengen Yogyakarta. Skripsi. Yogyakarta : Fakultas Kesehatan Masyarakat, Universitas Ahmad Dahlan. 2009.

23. Suhardjo. Pemberian Makanan Pada Bayi dan Anak. Yogyakarta : Kanisius. 2000.

24. Mazarina D. Tingkat Pendidikan Ibu Hubungannya Dengan Perilaku Makan dan Status Gizi Siswa SD. Makalah Falsafah Sains. IPB. 2004.

25. Soekidjo Notoatmodjo. Pendidikan dan Perilaku Kesehatan. Jakarta: Rineka Cipta. 2003.p 124-125 